Participatory Educational Research (PER)

Vol. 2(1), pp. 1-10, April, 2015

Available online at http://www.partedres.com

ISSN: 2148-6123

http://dx.doi.org/10.17275/per.14.16.2.1

\title{
New Trends on Mobile Learning in The Light of Recent Studies
}

\begin{tabular}{|c|c|}
\hline & asya University Technology Faculty, Amasya \\
\hline Article history & \multirow{7}{*}{$\begin{array}{l}\text { Since the beginning of the century, with the introduction of mobile } \\
\text { devices, use of the concept of mobile learning, became frequent, } \\
\text { along with e-learning, m-learning, concept began to come on the } \\
\text { agenda. It can be said that determining in what proportion and in } \\
\text { which axis m-learning concept discussed in the literature would be } \\
\text { important for revealing the issues that are not discussed enough } \\
\text { Starting from this basic premise, the purpose of this research is } \\
\text { examining the researches in the literature within the last three } \\
\text { years, and identifying new approaches. Literature review was } \\
\text { limited with ScienceDirect (one of international databases) and } \\
\text { Ulakbim (a database from Turkey). In the scope of the research, } 45 \\
\text { studies, } 37 \text { from Science Direct, } 8 \text { from Ulakbim Social Sciences } \\
\text { Database were selected. In the study, each article was investigated } \\
\text { with document analysis method. Articles were classified and } \\
\text { examined. According to five different criteria the results obtained } \\
\text { by this research are summarized as follows: Selected works from } \\
\text { Turkey are mostly descriptive studies which try to determine } \\
\text { students or faculty members' views. In almost all of these studies } \\
\text { the opinions of the students were determined but the information } \\
\text { about their past mobile learning experiences is not included in the } \\
\text { researches. The studies selected from ScienceDirect have highly } \\
\text { diversed subjects, they based on from different disciplines } \\
\text { different learning approaches and mostly try to find out the } \\
\text { effectiveness of a developed original environment. In addition, in } \\
\text { different subject areas in mobile learning, issues like students } \\
\text { academic achievements, attitudes and perceptions of influence, } \\
\text { teacher/teaching staff attitudes or perceptions, adaptable mobile } \\
\text { environments, cooperative mobile environments, mobile } \\
\text { environments self-regulated learning, mobile environments of } \\
\text { information presented in different ways the effects of game-based } \\
\text { mobile learning, note-taking with mobile tools, mobile applications } \\
\text { in formal education, and mobile augmented reality environments } \\
\text { become prominent. }\end{array}$} \\
\hline $\begin{array}{l}\text { Received: } \\
11.10 .2014\end{array}$ & \\
\hline $\begin{array}{l}\text { Received in } \\
28.12 .2014\end{array}$ & \\
\hline ce & \\
\hline 02.12 .2014 & \\
\hline $\begin{array}{l}\text { Key words: } \\
\text { Mobile Leart }\end{array}$ & \\
\hline based learning, & \\
\hline
\end{tabular}

*Correspondence:ozgenkorkmaz@gmail.com 


\section{Introduction}

In accordance with the technology-based developments, the idea of open learning is rapidly changing its shape and meaning, it has become mentioning with the concept of distance education. Conceptual change also accompanied with a semantic change, the idea, known as informal educational tool, has become an important part of formal education. In particular, the widespread of the blended teaching model, this trend has totally increased. Especially with the development and strengthening of internet infrastructure in the last 10 years, the concept of internet-assisted education or e-enabled education has been used frequently instead of the concept of distance education and it has caused that its applications has become common in formal education. However, in recent years with the introduction of mobile devices to daily life, rather than the concept of internet-assisted education or e-enabled education, the use of the concept of mobile learning has increased and e-learning has started to transform into m-learning. Especially nowadays, we can say that mobile devices are among the new technologies because of giving the user more freedom in time and space and their cost, mobile devices are very advantageous when compared with desktop computers (Oran and Karadeniz, 2007). In recent years, the studies in the literature have shown that a significant portion of the student population have smart phones and and tablets and they are able to run and use mobile applications.

Sharpless et al. (2005) and Cochrane (2010) have been stated that mobile learning's most important difference separated from all other types of learning is that learners can be in constant motion. As a matter of fact, the descriptions are on this axis. Quinn (2000) has expressed mobile learning as the use of handheld devices for learning. The first definition which revealed by Quinn (2000) was being discussed and it was adopted with some changes in essence. Çakır (2011) has been stated that mobile learning contain the situations that an important part of learning takes place out of school and form people activities to make educational processes and results possible. With easy accessibility and portability of mobile technology, learning activities such as drill and practice especially in the field of education can be carried out of the classroom (Saran, Seferoğlu and Çağıltay, 2009). Palmtop computers (PDAs), mobile phones and the tablet computers, which have become increasingly widespread can be used for educational purposes and it is possible to take advantage in the teaching-learning process with the support of educational institutions (Corlett et al, 2005). In the literature, it is possible to come across many studies confirming this idea (Thornton, Houser, 2005; Chinnery, 2006; Chang et al., 2011; Hsu and Ho, 2012; Ozan,2013; Reychav and $\mathrm{Wu}, 2014)$. Gay et al (2001) have been stated that mobile learning has many advantages such as engaging students with learning related activities in different physical environments, supporting group work in projects and improving communication and cooperative learning in the classroom.

Certainly, it is unthinkable that this potential is not be used for educational purposes. Besides the advantages of mobile learning, there are also many issues and constraints to discuss about mobile learning such as what should be design principles in mobile learning environments, what needs to be done and what kind of differences exist in instructional design for mobile environments, what kind of features required in a mobile learning management system and which platform or platforms will be selected for developing applications. It can be said that it is important to determine in what level and which axis these issues discussed in in the literature, in terms of enlightening the issues not discussed enough. Starting from this basic assumption, by examining within the last three years of research in the literature, the objective of this research identifies new approaches and reveals the situation in Turkey Especially in the last three years, there have been many important developments in IOS and Android platforms, 
smart phone technology, and also in the $3 \mathrm{G}$ mobile internet connection technology. These developments have also differentiated mobile learning oriented studies naturally. For this reason, the subject articles has been selected from the articles published in the last three years.

\section{Method}

In the study, each article has been examined to use the method of document analysis. Document analysis is a research technique for identification a content through objective, systematic and quantitative classification (Bauer, 2003). Document analysis method is an examination and review process of collected data related to the work, by encoding according to a particular system (Çepni, 2007). In addition to this, with regard to show how research subject evolve in time, document analysis method is useful in the longitudinal analysis (Cohen, Manion \& Morrison, 2007). In this study, content analysis has been made with the data collected by this method. Content analysis is based on the numerical representation of the certain characteristics of the studied data (Karasar, 2002).

Electronic sources have been used to access the selected studies for the research. The literature review is limited with articles published in the last three years in ScienceDirect from the international databases and in Ulakbim Social Sciences Database from Turkey. ScienceDirect database includes such journals as Computers \& Education, Computers in Human Behavior, Nurse Education, Safety Science and Higher Education. Ulakbim Social Sciences Database includes journals broadcasting from Turkey and in Turkish and majority of them are composed of education faculty journals. While searching, keywords such as "mlearning, mobile learning, mobile phones in learning, tablets, sms, mms" have been used together or separately in different compositions and it has been accessed 87 studies in total. From these accessed studies, 42 of them have been eliminated for the reasons of double results, being out of the field or not being a journal article. To decide whether an article is out of the field or not, it has been examined that mobile learning subject whether the first subject of the article and whether mobile devices were directly used for learning purposes. Thus, 37 studies from ScienceDirect and 8 studies from Ulakbim Social Sciences Database, a total of 45 studies, were selected in the scope of the research. In this context, this study is limited by the studies indexed these databases in the last 3 years.

The articles recruited for the study have been examined by classifying them according to five different criteria within the framework of the research methodology. These Criteria are (a) the purpose of the study, (b) characteristics of the study group (for example; primary school, secondary school, high school, higher education adult etc. ), (c) method (such as; survey, experimental, meta-analysis, qualitative, quantitative etc.), (d) courses or field of the study and (e) learning outcomes (such as; positive, negative and neutral). Similar criteria have been used previously by Wu et al (2012) and Küçük et al (2013) for the same purposes. However, these studies also have been included different criteria apart from these criteria. Within the scope of this research, the six identified criteria has been considered enough.

\section{Findings}

The selected mobile learning-related articles for the research have been analyzed separately for the 5 criteria as described above and the findings have been summarized as follows. 


\subsection{Studies By Distribution of Research Purpose}

Primarily, study subjects of the selected articles have been examined one by one. During the review process similar topics haven't been written separately, they have been combined and summarized. In this framework, the studied subjects have been summarized below:

The journals indexed in Ulakbim;

- Views of m-learning-oriented instructors

- Effectiveness of learning through SMS

- Development of a mobile software intended to memorize English words

- Students' opinions about the use of mobile technology

- Introducing Mobile cloud technology

- Forming learning materials for mobile devices with Moodle

- Students' opinions regarding mobile software designed for Fundamentals of Information Technology course

- Examination of academics opinions about the use of mobile technologies for educational purposes in the context of Technology Acceptance Model (TAM)

The Journals indexed in ScienceDirect;

- Effects of m-learning on students and teachers

- Examination of deductive scientific inquiry method with using mobile devices in class

- Effectiveness of applying different instructional strategies with Mobile learning WebQuests

- Students' perceptions towards m-learning in higher education

- Use of mobile learning for improvement of skills in thoracic surgery

- Supporting mobile learning for students who need special training

- Development and effectiveness of adaptive mobile learning environments

- Discussion of basic design principles for Mobile learning environments

- Perceptions of students towards learning through cell phones, smart phones and social media

- The game of mobile archeology's influence on learning.

- Design and implementation of a Competition-based mobile intelligent training system

- Personalized recommendations based mobile learning approach's impact on reading English performance

- Mobile learning approach's influence on attitude and academic achievement

- Comparison of two different mobile learning situation in Formal and semi-formal learning environments in terms of student control

- EcoMobile: augmented reality and integration of probeware to mobile environments

- A comparative analysis on game-based mobile learning model

- Unnecessary effects and distractions of mobile learning in physical environments

- Learning effects of presenting information in different formats in mobile environments

- A curriculum proposal for a course in accordance with 5E Learning Cycle Model for mobile lerning

- Mobile applications in non-formal education

- Development and evaluation of a 3d mobile application for manual therapy training in Psychiatry laboratory 
- Teachers' perceptions towards use of mobile phones in classroom

- Use of mobile tablets in traffic education

- Collaborative mobile learning environments

- Acceptance level of university students' taking mobile notes dissemination

- Self-regulated learning in mobile learning environments

- Use of mobile technology in order to form nested learning interactions

- Mobile learning activities for clinical nursing education

- The effectiveness of the automatic text summarization in mobile learning contents

When study subjects of Turkey addressed studies in the above-mentioned are examined, it is seen that they are mostly descriptive studies for determining opinions of students or faculty members. However, in determining these opinions, almost all of the studies don't include whether the students have experienced a mobile learning experience before or if they have experienced it before how was the experience. When ScienceDirect addressed studies are examined, it is seen that study issues are highly diversified, different learning approaches for different disciplines are taken and studies are mostly in the axis of the effectiveness of the developed original environment.

To determine the structural tendency of these study issues, a classification according to the purposes of the studies was performed. In the classification period, the criteria which is used by $\mathrm{Wu}$ et al (2012) was used. In this context, four purpose criteria were used. These are; (1) evaluation of the effectiveness of mobile learning, (2) mobile environment design for learning, (3) cognitive variables in the process of mobile learning and (4) effects of learners' characteristics in mobile learning process. However, the last one of these criteria was discarded because there is no study according to the criteria. Distribution of the studies by these categories are summarized in table 1.

Table 1. Distribution of the studies by purpose

\begin{tabular}{lcl}
\hline Purposes & ScienceDirect (f) & Ulakbim (f) \\
\hline A1. Evaluation of the effectiveness of mobile learning & 23 & 2 \\
A2. Mobile environment design for learning & 3 & 2 \\
A3. Cognitive variables in the process of mobile learning & 11 & 4 \\
\hline
\end{tabular}

When Table 1 is analyzed, it is seen that a very important part of the studies about mobile learning aims to evaluate the effectiveness of the developed mobile environment and examine cognitive variables. On the other hand, few studies issue mobile environment design. Therefore, it is seen that mostly cognitive processes are entreated in Turkey addressed studies.

\subsection{Studies By Distribution of Research Method}

When classifying methods of the studies according to their purposes, the studies have been classified for each purpose indicated in Table 1 separately. As in the study conducted by Küçük et al (2013), research methods have been divided into three categories as qualitative, quantitative and mixed at first, then they have been divided again into sub-categories as descriptive survey method, experimental research method, relational method and metaanalysis. However, the categories which any study classified in have been deleted subsequently The distribution of the studies within those categories are summarized in Table 2 . 
Table 2. Studies by distribution of research method

\begin{tabular}{|c|c|c|c|c|c|c|c|}
\hline \multirow{2}{*}{$\begin{array}{c}\text { Research } \\
\text { Methodology }\end{array}$} & \multirow[t]{2}{*}{ Research Method } & \multicolumn{3}{|c|}{$\begin{array}{l}\text { ScienceDirect } \\
\text { (f) }\end{array}$} & \multicolumn{3}{|c|}{$\begin{array}{l}\text { Ulakbim } \\
\text { (f) }\end{array}$} \\
\hline & & A1 & A2 & A3 & A1 & A2 & A3 \\
\hline \multirow[t]{3}{*}{ Qualitative } & Descriptive Survey & & 1 & 3 & 1 & & 3 \\
\hline & Experimental & 2 & & & & & \\
\hline & Relational/Case Study & & & 2 & & & \\
\hline \multirow[t]{3}{*}{ Quantitative } & Descriptive Survey & 3 & 1 & 4 & & & 1 \\
\hline & Experimental & 17 & & & & & \\
\hline & Relational/Case Study & & & 2 & & & \\
\hline \multirow[t]{3}{*}{ Mixed } & Descriptive Survey & 1 & & & & & \\
\hline & Experimental & & & & 1 & & \\
\hline & Relational/Case Study & & & & & & \\
\hline \multicolumn{2}{|c|}{ Development of M-Learning environment } & & 1 & & & 2 & \\
\hline
\end{tabular}

When Table 2 is analyzed, it is seen that a significant portion of the studies have been carried out with quantitative research methodology and there are very few studies have been carried out with mixed research methodology. In terms of purposes of the studies, it is obvious that a significant portion of the effect studies have been performed using the experimental patterns and descriptive survey research methods or case studies have been conducted in studies on cognitive variables. Besides, it is seen that mostly descriptive survey method has been performed in Turkey addressed studies.

\subsection{Studies By Distribution of Participants' Characteristics}

The studies have been classified and categorized for each purpose separately according to study groups. The distribution of the studies within those categories are summarized in Table 3.

Table 3. Studies by distribution of participants' characteristics

\begin{tabular}{lllllll}
\hline Learning Level & \multicolumn{3}{l}{ ScienceDirect (f) } & \multicolumn{3}{c}{ Ulakbim (f) } \\
\cline { 2 - 7 } & A1 & A2 & A3 & A1 & A2 & A3 \\
\hline Primary School & 5 & & & & & \\
Secondary School & 4 & 1 & & & & \\
High School & 1 & 1 & 1 & & & \\
Higher Education & 9 & & 4 & 1 & 1 & 2 \\
Instructor/Teacher & & & 2 & & & 2 \\
Informal Education & 4 & & 3 & & & \\
\hline
\end{tabular}

When Table 3 is analyzed, it is seen that study groups of the studies are concentrated in higher education, but also there are significant amount of studies at the level of primary and secondary schools. The number of studies is relatively small at high school level. When we look at Turkey addressed studies, it is obvious that studies have been conducted only in higher education, there are no studies in primary and secondary schools.

\subsection{Application Course of Research/Field of Study}

The studies have been classified and categorized for each purpose separately according to application courses of the studies and their fields. The distribution of the studies within those categories are summarized in Table 4. 
Table 4. Distribution of the studies by application course of research/field of study

\begin{tabular}{lcccccc}
\hline Course/ Field of Study & \multicolumn{3}{c}{ ScienceDirect (f) } & \multicolumn{3}{c}{ Ulakbim (f) } \\
\cline { 2 - 7 } & A1 & A2 & A3 & A1 & A2 & A3 \\
\hline Educational Technology & 2 & & & & & 1 \\
English Education & 1 & & 1 & 1 & 1 & 1 \\
Computer Education & 1 & & & & & 1 \\
Science Education & 5 & 2 & & & & \\
Special Education & 1 & & & & & \\
Archaeology & 1 & & & & & \\
Environmental Education & 1 & & & & & \\
Safety Education & 4 & & & & & \\
Traffic Education & 1 & & & & & \\
Mathematics Education & 1 & & & & & \\
Social Sciences & 1 & & 1 & & & \\
Medical/Nursing Education & 3 & & 1 & & & \\
\hline
\end{tabular}

When Table 4 is analyzed, it is seen that, especially in the studies out of Turkey, effectiveness research oriented to different courses like science education, safety education an medical/nursing education have been made. But in Turkey, these studies have been concentrated on English education.

\subsection{Distribution by Learning Outcomes}

The studies have been classified and categorized for each purpose separately according to positive, negative and neutral learning outcomes. The distribution of the studies within those categories are summarized in Table 5.

Table 5. Distribution by Learning Outcomes

\begin{tabular}{|c|c|c|c|c|c|c|c|c|c|}
\hline \multirow[t]{2}{*}{ Course/ Field of Study } & \multicolumn{4}{|c|}{ Scientificdirect (f) } & \multicolumn{4}{|c|}{ Ulakbim (f) } & \\
\hline & $\mathrm{A} 1$ & A2 & $\mathrm{A} 3$ & $\mathrm{~A} 4$ & $\mathrm{~A} 1$ & $\mathrm{~A} 2$ & $\mathrm{~A} 3$ & A4 & A5 \\
\hline Positive & 25 & 1 & 4 & & 1 & & 4 & & \\
\hline $\begin{array}{l}\text { Negative } \\
\text { Neutral }\end{array}$ & 1 & & & & & & & & \\
\hline
\end{tabular}

In terms of learning outcomes within the scope of the research, the studies are analyzed and it is revealed that, all studies have positive outcomes except one.

\section{Results and Discussion}

Studies that addressed Turkey are mostly descriptive studies oriented to determine opinions of tudents or faculty members. In determining these opinions, almost all of these studies doesn't include whether participant students have experienced A mobile learning experience before and if they had, what kind of experience it is. On the other hand, in ScienceDirect addressed studies, issues are varied considerably, oriented to different disciplines, based on different learning approaches and mostly in the axis of development and effectiveness of an original environment. In addition, different subject areas in mobile learning, issues such as students' academic achievements and its impact on the attitudes and perceptions, attitudes or perceptions of teachers/faculty members, adaptive mobile environments, cooperative mobile environments, self-regulated learning in the mobile environments the effects of the information presentation with different ways in the mobile environments, game-based mobile learning, using mobile devices to take notes, mobile applications in non-formal education and augmented reality in mobile environments become prominent. Besides, a purpose classification has been subjected to determine structural orientation of the study issues. According to this classification, it has been reached that a very 
important part of the studies about mobile learning aim to evaluate of the effectiveness of the designed mobile environment and examine cognitive variables. A small number of the studies issue only environment design. In a meta-analysis study about mobile learning which is covering the years from 2003-2010 and conducted by Wu et al (2013), it has been reached similar findings, it has been stated that $58 \%$ of the 164 studies in the research are oriented for effectiveness. Likewise, in a meta-analysis study on game-based learning by Vogel (2006), it has been expressed the intensity of effectiveness studies. When we look Turkey addressed studies, it has been seen that research is done mostly for cognitive processes and there is no studies looking into the effectiveness of a designed environment. In a study conducted by $\mathrm{Wu}$ et al (2012), it has been said that environment design studies follow effectiveness studies, but in this study it has been standed out that the studies for this purpose are at least. However, it has been tested the effectiveness of the designed environment in a significant portion of effectiveness studies. Fort his reason, although media design elements have been included in these studies, these studies have been classified as effectiveness studies. This may have been caused environment studies to appear in a small number.

When methods of the studies included in this research are examined; it has been seen that quantitative research methodology has been used in majority of the studies and qualitative research methodology has been used in a minority. Although Göktaş et al (2012) and Kelly \& Lesh (2000) state that qualitative research methodology, started to be more preferred than quantitative methodology in recent years, it's reached reached an opposite conclusion in this study. The reason for this may have been the experimental research methods preference about mobile learning recently. In addition, it's obvious that the number of mixed research methodology studies are very small. In terms of purposes, experimental research methods have been used in a significant portion of effectiveness studies, descriptive survey and case study methods have been performed in the studies on cognitive variables. Moreover, studies addressed Turkey have been carried out mostly with the model of descriptive survey. In a study conducted by Wu et al (2012), it has been stated that the most preferred method is the survey method and it's followed by experimental methods. Also according to the same research, it has been stated that quantitative approaches are more prefered than qualitative approaches. In a distance education oriented study conducted by Zawacki-Richter et al (2009) covering distance education studies between 2000-2008, it's possible to reach similar findings. In a study conducted by Küçük et al (2013), 1151 studies in the field of educational technology, which carried out in Turkey between the years of 1990-2011 have been examined and it has been expressed that quantitative methods are more prefered than qualitative methods. In the study of Küçük et al (2013), in contrast to this study, it has been stated the models that are not experimental are more preferred. In contrast to the literature, the adoption of the experimental methods in the research on mobile learning may have been resulted from these following reasons; this is a very new field, wherefore it is not yet widespread, and for descriptive research appropriate working groups who have experience in mobile learning are very few.

Working groups of the studies are focused in higher education. However, there are a significant number of work at the level of primary and secondary schools. In the meantime, the number of studies is relatively small at high school level. On the other hand, when Turkey-based publications are examined, it can be said that studies have been conducted only in higher education, there are no studies conducted in primary and secondary schools. Similar results have been achieved in the studies conducted by Küçük et al (2013), Göktaş et al (2012) and Şimşek et al (2009). This stiuation may be caused by the following reasons; the age range which may own this technology is generally in the higher education, necessity of 
students who have high self-regulatory learning skills to take advantage of this type of technology and similarly, students who have this capability are mostly at the university level and because of researchers are already working in this education level, they access these students to be more easily.

In particular in the studies from abroad, research has been done oriented on the effectiveness of different courses especially science education, safety education, medical/nursing education. Outside of these featured fields, research has been carried out oriented to the use of mobile learning in the fields of Educational Technology, English Education, Computer Education, Special Education, Archaeology, Environmental Education, Traffic Education, Mathematics Education and Social Sciences. As for Turkey, it's seen that these studies are focused on English education.

When the research studies are examined in terms of learning outcomes within the scope of the research, positive outcomes have been demonstrated in all studies except one study. Similar findings have been found in the studies conducted by Wu et al (2012) and Ke (2009). This circumstance has been showed that supporing the levels of student learning by mobile devices can provide an important contribution, there is a significant potential in this technology in terms of education and investing in this field may be important for the future.

Consequently, it can not be said that mobile learning issues have been discussed sufficiently in the literature. Besides, it can be said that these following issues haven't been discussed enough yet in the literature; mobile learning's impact on different courses, with different learning and design approaches, with different interaction approaches and its impact on different cognitive variables, when designing a mobile environment which design principles should be taken into account, when developing a mobile environment for educational purposes which instructional design approach should be preferred, how to integrate these technologies into the curriculum, the examination of mobile learning environments in terms of individual differences. In this context and in parallel with the international literature, as a suggestion for further studies, it can be said that each of these issues can be addressed as a research subject, these studies can be expanded and carried out in other education levels except higher education in order to contribute the integration of mobile learning technologies in the Turkish education system.

\section{Acknowledgement}

This paper has been presented as oral presentatin on 2th International Instructional Technologies \& Teacher Education Symposium 2014

\section{References}

Bauer, M. W. (2003). Classical content analysis: A review. In M. W. Bauer, \& G. Gaskell (Eds.), Qualitative researching with text, image and sound (pp. 131-151). London: Sage Publication

Chang, C., Chen,T., Hsu, W. (2011). The study on integrating WebQuest with mobile learning for environmental Education. Computers \& Education 57: 1228-1239

Cochrane, T. (2010). Mobile web 2.0: Bridging learning contexts. In S. Caballé, F. Xhafa, T. Daradoumis, \& A. A. Juan, Architectures for distributed and complex m-learning systems: Applying intelligent technologies (s. 123-151). UAS: Information Science Reference. 
Cohen, L., Manion, L., Morrison, K. (2007). Research Methods in Education (6th Ed.). NY: Routledge.

Corlett, D., Sharples, M., Bull, S. ve Chan, T. (2005). Evaluation of a mobile learning organiser for university students. Journal of Computer Assisted Learning, 21, 162-170.

Çakır, H. (2011). Mobil öğrenmeye ilişkin bir yazılım geliştirme ve değerlendirme. [A software development and evaluation of mobile learning] Cukurova University Faculty of Education Journal: 40:, 01-09

Çepni, S. (2007). Araştırma ve proje çalışmalarına giriş (3.Baskı), Methods and classifications used in educational research,Trabzon: Celepler Pub: 76.

Gay, G., Stefanone, M., Grace-Martin, M. \& Hembrooke, H. (2001) The effects of wireless computing in collaborative learning environments. International Journal of HumanComputer Interaction, 13(2): 257-276.

Goktas, Y., Kucuk, S., Aydemir, M., Telli, E., Arpacik, O., Yildirim, G., \& Reisoglu, I. (2012). Educational technology research trends in Turkey: A content analysis of the 2000-2009 decade. Educational Sciences: Theory \& Practice, 12(1), 177-199

Hsu, C., Ho, H. (2012).The design and implementation of a competency-based intelligent mobile learning system. Expert Systems with Applications 39: 8030-8043

Karasar, N. (2002). Bilimsel araştırma yöntemi [Research Methods], 11.Press, Ankara: Nobel Pub.

Kelly, A. E., \& Lesh, R. A. (2000). Trends and shifts in research methods. In A. E. Kelly, \& R. A. Lesh (Eds.), Handbook of Research Design in Mathematics and Science Education (pp.35-44). Mahwah, NJ: Lawrence Erlbaum Associates.

Kucuk, S., Aydemir, M., Yildirim, G., Arpacik, O., Goktas, Y. (2013). Educational technology research trends in Turkey from 1990 to 2011. Computers \& Education 68 (2013) 42-50.

Oran, M.K. ve Karadeniz, Ș. (2007). The role of mobile learning role in intenet based distance education. Available at: http://ab.org.tr/ab07/bildiri/66.pdf

Ozan, Ö. (2013): Bağlantıcı mobil öğrenme ortamlarında yönlendirici destek [Connectionism router support mobile learning environment]. Unpublished PhD Thesis . Anadolu University.

Quinn, C. N. (2000). mLearning: Mobile, wireless, in-your-pocket learning. http://www.linezine.com/2.1/features/cqmmwiyp.htm

Reychav, I., Wu, D. (2014). Exploring mobile tablet training for road safety: A uses and gratifications perspective. Computers \& Education 71 (2014) 43-5.5

Saran, M., Seferoğlu, G. ve Çağıltay, K. (2009). Mobile assisted language learning: English pronunciation at learners' fingertips. Eurasian Journal of Educational Research,34, 97-114.

Sharples, M., Taylor, J., Vavoula, G. (2005). Towards a Theory of Mobile Learning. In Proceedings of m-learn Conference, Cape Town:2005, South Africa.

Simsek, A., Ozdamar, N., Uysal, O., Kobak, K., Berk, C., Kilıcer, T., et al. (2009). Current trends in educational technology research in Turkey in the new millennium. Educational Sciences: Theory \& Practice, 9(2), 941-996.

Vogel, J. J., Vogel, D. S., Canon-Bowers, J., Bowers, C. A., Muse, K., \& Wright, M. (2006). Computer gaming and interactive simulation for learning: a meta-analysis. Educational Computing Research, 34, 229-243.

Wu, W., Jim Wu, Y., Chen, C., Kao, H., Lin, C, Huang, S. (2012). Review of trends from mobile learning studies: A meta-analysis. Computers \& Education 59 (2012) 817827. 
Zawacki-Richter, O., Bäcker, E. M., \& Vogt, S. (2009). Review of distance education research (2000 to 2008): analysis of research areas, methods, and authorship patterns. International Review of Research in Open and Distance Learning, 10(6), 21-45. 